\title{
Pengaruh Asupan Nutrisi pada Bayi Prematur dengan Pertumbuhan Ekstrauteri Terhambat di Rumah Sakit Anak Bunda Harapan Kita
}

\author{
Toto Wisnu Hendrarto, ${ }^{1}$ Wida Ayu Nurahma, ${ }^{2}$ Marpauling, ${ }^{2}$ Karina ${ }^{2}$ \\ ${ }^{1}$ Kelompok Kerja Neonatologi Rumah Sakit Anak dan Bunda Harapan Kita, Jakarta \\ ${ }^{2}$ Asisten Unit Koordinasi Kerja Neonatologi PP IDAI
}

Latar belakang. Tantangan tatalaksana bayi prematur adalah terjadinya pertumbuhan ekstra uteri terhambat karena kecukupan nutrisi tidak sesuai dengan kebutuhan pertumbuhannya.

Tujuan. Mengetahui distribusi terjadinya PEUT menurut asupan jenis nutrisinya.

Metode. Penelitian deskriptif retrospektif dari rekam medik bayi prematur dirawat di Rumah Sakit Anak Bunda Harapan Kita pada Juli 2018 - Juli 2019.

Hasil. Penelitian ini melibatkan 128 bayi prematur. Jenis asupan nutrisi yang diterima adalah ASI, ASI dengan fortifikasi human milk fortifier, ASI dengan susu formula prematur dan susu formula prematur saja. Bayi prematur yang mengalami PEUT berjumlah 55 (43\%). Risiko terjadinya PEUT 1,08 dan 1,78 berturut-turut pada ASI dibandingkan dengan susu formula serta ASI dibandingkan dengan ASI ditambah HMF. Percepatan pertumbuhan tertinggi pada kelompok PEUT yang mendapat ASI dengan fortifikasi HMF (14 gram $/ \mathrm{kgBB} / \mathrm{hari})$, terendah pada kelompok susu formula prematur $(4,6$ gram $/ \mathrm{kgBB} / \mathrm{hari})$. Percepatan kenaikan berat badan hampir sama pada semua bayi prematur dalam kelompok pertumbuhan normal $(11,5-13,7 \mathrm{gram} / \mathrm{kgBB} / \mathrm{hari})$.

Kesimpulan. Air susu ibu adalah pilihan terbaik dalam pemberian introduksi nutrisi enteral pada periode kritis perawatan bayi prematur. Jenis nutrisi enteral pada periode pertumbuhan disesuaikan dengan kecukupan kebutuhan masing-masing bayi prematur. Sari Pediatri 2020;22(3):169-75

Kata kunci: bayi prematur, pertumbuhan ekstra uteri terhambat, jenis nutrisi

\section{The Effect of Nutrition Intake in Preterm Infants with Extrauterine Growth Restriction in Harapan Kita Women and Children}

\begin{abstract}
Toto Wisnu Hendrarto, ${ }^{1}$ Wida Ayu Nurahma, ${ }^{2}$ Marpauling, ${ }^{2}$ Karina ${ }^{2}$
Background. Extrauterine growth restriction (EUGR) is a challenge in the management of preterm infants because of the imbalance of nutritional requirements on their growth phase.

Objective. To find out the distribution of growth patterns in preterm infants according to their nutritional regiments.

Methods. This research data was based on medical record of preterm infants while they were hospitalized in Harapan Kita Women and Children Hospital, from July 2018 - July 2019. Results: About 128 preterm infants were included in the study. Nutrition that they received was breastmilk, breastmilk with human milk fortifier (HMF), breastmilk with preterm formula and only preterm formula. Results. The incidence of EUGR was 55 (43\%). Risk of occurrence of EUGR 1,08 and 1,78 successively in breastmilk compared to preterm formula and breastmilk compared to breastmilk with HMF. The highest and lowest weight velocity of preterm infants was $14 \mathrm{~g} / \mathrm{kg} / \mathrm{d}$ and $4,6 \mathrm{~g} / \mathrm{kg} / \mathrm{d}$ in breastmilk with HMF and only preterm formula group, respectively. The growth velocity was not significantly different in the preterm infants within normal group $(11,5-13,7 \mathrm{~g} / \mathrm{kg} / \mathrm{d})$.

Conclusion. Breastmilk is the best choice for preterm infants, especially on feeding introduction and critical ill condition. Moreover, for optimal growth, preterm infants need the optimal adjustable composition of nutrition based on each requirement. Sari Pediatri
\end{abstract} 2020;22(3):169-75

Keywords: preterm infants, low birth weight, extrauterine growth restriction, nutrition intake

Alamat korespondensi: Toto Wisnu Hendrarto. RSAB Harapan Kita, Jl. Letjen S.Parman, St No Kav 87, Jakarta Barat. 11420. Indonesia. Telepon +628128919191. Email: twh_921@yahoo.com 
Toto Wisnu Hendrarto dkk: Pengaruh asupan nutrisi pada bayi prematur dengan pertumbuhan ekstrauteri terhambat

K elahiran prematur merupakan kegawatan nutrisi karena bayi terpaksa lahir pada periode pertumbuhan tertinggi intra uteri. Untuk itu, prinsip utama perawatan bayi prematur selain memberikan tunjangan oksigenisasi, juga harus memperhatikan kecukupan nutrisi untuk mempertahankan pertumbuhan intra uteri pasca lahir. ${ }^{1 \text {, }}$

${ }^{2}$ Upaya yang dilakukan adalah dengan memberikan tunjangan nutrisi agresif dini meliputi unsur protein, lemak sebagai sumber kalori non-protein juga nutrisi enteral dini untuk merangsang pertumbuhan vili-vili usus. $^{3}$

Pemberian enteral dan parenteral nutrisi agresif dini sangat bermanfaat untuk meningkatkan tumbuh kembang bayi prematur dengan berat lahir rendah. ${ }^{4}$ Pada bayi dengan berat lahir rendah dan prematur, tanpa asupan nutrisi energi dan protein yang adekuat dapat menyebabkan pertumbuhan ekstra uteri terhambat pada bayi. ${ }^{5,6}$ Air susu ibu merupakan unsur terbaik untuk memenuhi kebutuhan nutrisi enteral, tetapi komposisi ASI prematur belum dapat memenuhi kebutuhan protein dan mikronutrien bagi bayi prematur. ${ }^{7}$ Pemberian fortifikasi human milk fortifier (HMF) merupakan salah satu cara untuk memenuhi kecukupan kebutuhan nutrien. ${ }^{8}$ Bagi bayi prematur yang tidak dapat menerima ASI dan fortifikasinya secara optimal, dapat diberikan susu formula standar prematur atau dikombinasikan dengan ASI. ${ }^{9}, 10$

Pertumbuhan ekstrauteri terhambat (PEUT) terjadi ketika berat badan dan atau panjang badan di bawah persentil 10 dari ekspektasi pertumbuhan intra uteri. ${ }^{11,12}$ Angka kejadian PEUT merupakan isu yang serius dalam tatalaksana BBLR dengan angka kejadian 28\%, 34\%, $16 \%$ berhubungan dengan berat, panjang badan, dan lingkar kepala. ${ }^{13}$

Faktor prenatal yang juga dapat memengaruhi ialah adanya komplikasi selama kehamilan, seperti solusio plasenta, pre-eklampsia/ eklampsia, diabetes gestasional. ${ }^{6}$ Selain itu, multiparitas, oligohidramnion, intrauterine growth retardation (IUGR), morbiditas multipel seperti distress napas, bronchopulmonary dysplasia (BPD) dan sepsis juga merupakan faktor yang berhubungan dengan pertumbuhan ekstra uteri terhambat pada usia koreksi 6 bulan. ${ }^{14-16}$

Faktor asupan nutrisi dan PEUT memiliki hubungan yang saling berkaitan. Pada penelitian yang dilakukan Tozzi $\mathrm{dkk}^{6}$ menunjukkan kandungan protein yang terdapat pada asupan nutrisi berhubungan dengan pertumbuhan ekstra uteri terhambat. Kandungan protein pada asupan nutrisi yang semakin tinggi, dapat menurunkan risiko terjadinya pertumbuhan ekstra uteri terhambat yaitu faktor pertumbuhan berat badan pada bayi lahir prematur dan bayi dengan berat badan lahir rendah. Selain itu, asupan lemak rendah juga memiliki peran penting dalam pertumbuhan ekstra uteri terhambat ${ }^{6}$ Tujuan penelitian ini adalah untuk mengetahui PEUT dengan mengukur berat badan terakhir bayi prematur berdasarkan asupan nutrisi dana percepatan kenaikan berat badan berdasarkan asupan nutrisi.

\section{Metode}

Penelitian ini merupakan penelitian deskriptif retrospektif kohort yang dilakukan pada Rumah Sakit (RS) Anak Bunda Harapan Kita, Jakarta. Penelitian ini dilakukan selama 3 bulan, sejak Agustus 2019 hingga Oktober 2019. Selama periode ini dilakukan penelusuran rekam medis bayi prematur yang dirawat di RSAB sejak Juli 2018 hingga Juli 2019, baik yang lahir di rumah sakit dan rujukan dari luar rumah sakit. Persetujuan izin penelitian telah disetujui sebelum penelitian ini berlangsung. Penelitian ini dilakukan pada semua bayi yang lahir sebelum usia gestasi 37 minggu. Penelitian ini mengeksklusi bayi yang memiliki kelainan bawaan, bayi lahir meninggal, ataupun bayi yang meninggal selama masa perawatan. Selain itu, bayi yang putus kontrol dan data tidak lengkap juga dieksklusi dari penelitian ini. Data sekunder yang didapat adalah jenis kelamin, usia gestasi, metode kelahiran, data antropometri (berat badan, panjang badan dan lingkar kepala) saat lahir, berat badan terendah saat perawatan, lama perawatan, berat badan saat pulang, serta berat badan saat terakhir pemeriksaan di poli rawat jalan dan asupan nutrisi. Bayi prematur diklasifikasikan menjadi prematur (usia gestasi 32-37 minggu), sangat prematur (usia gestasi 28-32 minggu), dan amat sangat prematur (usia gestasi di bawah 28 minggu). Usia gestasi ditentukan dengan perkiraan hari pertama haid terakhir. Asupan nutrisi yang diberikan berupa ASI, ASI dengan fortifikasi HMF, kombinasi ASI dan susu formula, serta susu formula prematur. Berat badan lahir, berat badan terendah, berat badan saat pulang dari perawatan dan berat badan kontrol terakhir diinterpretasikan ke dalam Grafik Fenton. Bayi di bawah persentil 10 dianggap sebagai PEUT.

Data dimasukan ke dalam excel spreadsheat dan dianalisis menggunakan statistical package for social 
science (SPSS) versi 25. Pembagian asupan nutrisi dan odd ratio dihitung. Percepatan kenaikan berat badan dihitung dengan rumus. ${ }^{17}$

$$
\frac{((\mathrm{BB} 2-\mathrm{BB} 1) /(\mathrm{H} 2-\mathrm{H} 1))}{([(\mathrm{BB} 1+\mathrm{BB} 2) / 2] / 1000)}
$$

\section{Hasil}

Penelitian ini melibatkan 321 bayi prematur yang dirawat di RS Anak Bunda Harapan Kita. Bayi prematur yang masuk dalam kriteria inklusi sebanyak 128 bayi prematur, sisanya dieksklusikan karena memiliki kelainan kongenital, 75 bayi putus kontrol, dan 8 bayi dengan data tidak lengkap. Karakteristik populasi terbanyak memiliki usia kehamilan 32-<37 minggu $(61,7 \%)$, berat badan lahir terbanyak pada $\geq 1500$ gram $-<2500$ gram, mengalami penurunan berat badan $<15 \%$ sebanyak 123 (96,1\%) bayi (Tabel 1).

Bayi prematur yang mendapatkan asupan nutrisi ASI dengan fortifikasi HMF jumlahnya paling sedikit $(12,5 \%)$ dibandingkan dengan yang mendapatkan asupan nutrisi ASI $(25,8 \%)$, ASI dengan susu formula standar prematur $(39,1 \%)$, dan susu formula standar prematur saja $(22,7 \%)$.

Pada Tabel 2 ditunjukkan distribusi PEUT dan normal serta asupan nutrisi yang diterima pada penelitian ini. Bayi prematur yang mengalami PEUT adalah 55 (43\%). Bayi terbanyak mengalami PEUT adalah bayi yang mendapatkan ASI dengan fortifikasi HMF (56,3\%). Sebaliknya, bayi dengan pertumbuhan normal umumnya diberikan ASI, baik ASI dengan susu formula standar prematur serta susu formula standar prematur saja. Berdasarkan kedua kelompok tersebut dilakukan analisis distribusi dengan metode Chi-square dengan hasil tidak ada perbedaan bermakna antara terjadinya PEUT pada kelompok bayi prematur yang mendapatkan ASI dan kombinasi ASI (ASI dengan fortifikasi HMF dan ASI dengan susu formula standar prematur, $p>0,05)$. Risiko terjadinya PEUT hampir sama antara bayi prematur yang diberikan ASI dan susu formula standar prematur, sedangkan pemberian ASI dengan fortifikasi HMF memiliki risiko terjadinya PEUT 1,78 lebih tinggi.

Pada Tabel 3 dijelaskan percepatan kenaikan berat badan pada kelompok PEUT dialami pada bayi prematur yang mendapatkan ASI dan Fortifikasi HMF

Tabel 1. Karakteristik penelitian

\begin{tabular}{llcc}
\hline Variabel & & $\mathrm{n}$ & $\%$ \\
\hline Jenis kelamin & Laki-laki & 64 & 50,0 \\
Usia gestasi & Perempuan & 64 & 50,0 \\
& Amat sangat prematur (<28 minggu) & 4 & 3,1 \\
& Sangat prematur (28 - <32 minggu) & 45 & 35,2 \\
Metode lahir & Prematur (32 - <37 minggu) & 79 & 61,7 \\
& Sectio Caesaria & 110 & 85,9 \\
Berat badan lahir & Spontan & 18 & 14,1 \\
& BBLASR (<1000 gram) & 5 & 3,9 \\
Perawatan UPIN & BBLSR (<1500 gram) & 33 & 25,8 \\
& BBLR (<2500 gram) & 90 & 70,3 \\
Penurunan berat badan & Melewati perawatan UPIN & 60 & 46,9 \\
selama perawatan & Rawat gabung & 68 & 53,1 \\
Asupan nutrisi & Penurunan berat badan lebih dari 15\% & 5 & 3,9 \\
& Penurunan berat badan kurang dari 15\% & 123 & 96,1 \\
& ASI & 33 & 25,8 \\
Interpretasi Fenton & ASI dan HMF & 16 & 12,5 \\
& Susu formula dan ASI & 50 & 39,1 \\
& Susu formula prematur & 29 & 22,7 \\
& Di bawah persentil 10 & 55 & 43,0 \\
& Di atas persentil 10 & 73 & 57,0 \\
\hline
\end{tabular}


Toto Wisnu Hendrarto dkk: Pengaruh asupan nutrisi pada bayi prematur dengan pertumbuhan ekstrauteri terhambat

Tabel 2. Distribusi pasien berdasarkan Grafik Fenton dan asupan nutrisi

\begin{tabular}{lcccccc}
\hline & \multicolumn{5}{c}{ Interpretasi Fenton } \\
\cline { 2 - 7 } Asupan nutrisi & \multicolumn{1}{c}{ Di bawah persentil 10} & Di atas persentil 10 & \multicolumn{2}{c}{ Total } \\
\cline { 2 - 7 } & $\mathrm{N}$ & $(\%)$ & $\mathrm{N}$ & $(\%)$ & $\mathrm{N}$ & $(\%)$ \\
\hline ASI & 13 & 39,4 & 20 & 60,6 & 33 & 100 \\
ASI dengan fortifikasi HMF & 9 & 56,3 & 7 & 43,8 & 16 & 100 \\
ASI dengan SFP & 21 & 42,0 & 29 & 58,0 & 50 & 100 \\
SFP & 12 & 41,4 & 17 & 58,6 & 29 & 100 \\
\hline Total & 55 & 43,0 & 73 & 57,0 & 128 & 100 \\
\hline
\end{tabular}

Tabel 3. Rata-rata percepatan kenaikan berat badan

\begin{tabular}{lcccccc}
\hline \multirow{2}{*}{ Asupan nutrisi } & \multicolumn{5}{c}{ Percepatan kenaikan BB (gram/Kg/hari) } \\
\cline { 2 - 7 } & \multicolumn{3}{c}{$\begin{array}{c}\text { Pertumbuhan ekstrauteri } \\
\text { terhambat }\end{array}$} & \multicolumn{3}{c}{ Normal } \\
\cline { 2 - 8 } & Rerata & $\mathrm{N}$ & $(\%)$ & Rerata & $\mathrm{N}$ & $(\%)$ \\
\hline ASI & 9,11 & 13 & 23,6 & 11,54 & 20 & 27,4 \\
ASI dengan fortifikasi HMF & 14 & 9 & 16,4 & 11,5 & 7 & 9,6 \\
ASI dengan SFP & 7,39 & 21 & 38,2 & 13,71 & 29 & 39,7 \\
SFP & 4,64 & 12 & 21,8 & 13,16 & 17 & 23,3 \\
\hline Total & 8,28 & 55 & 100 & 12,78 & 73 & 100 \\
\hline
\end{tabular}

(14 gram $/ \mathrm{kgBB} /$ hari) dengan terjadinya PEUT paling sedikit $(16,4 \%)$. Sebaliknya, percepatan kenaikan berat badan pada kelompok normal hampir sama yaitu sekitar 11,5-13,71 gram/kgBB/hari.

\section{Pembahasan}

Penelitian retrospektif ini menggambarkan kejadian PEUT pada bayi prematur terbanyak di usia kehamilan $>32-<37$ minggu di RSAB Harapan Kita dengan angka kejadian sekitar 43\%. Kejadian ini serupa dengan penelitian Paudel ${ }^{18}$ pada tahun 2018. Paudel melaporkan kejadian kelahiran prematur terbanyak adalah prematur dengan usia kehamilan $>32-<37$ minggu (66,7\%), diikuti oleh kelahiran usia kehamilan sangat prematur $(29 \%)$, dan amat sangat prematur $(4.3 \%)^{8}$

Pada metaanalisis, manfaat fortifikasi HMF pada ASI didapatkan kejadian PEUT berkurang. Hal ini didukung pada penelitian yang dilakukan oleh Kumar dkk ${ }^{7}$ pada tahun 2017. Kumar melaporkan bahwa memberikan ASI saja pada bayi prematur memberikan hasil pertumbuhan yang lebih lambat dan memperlambat peningkatan lingkar kepala dibandingan dengan pemberian HMF.7 Penelitian dari Kumar dan Agostini menjelaskan bahwa ASI adalah pilihan terbaik karena superioritas yang dimilikinya, tetapi hanya sesuai pada periode introduksi pemberian nutrisi enteral dan keadaan kritis BBLR. Pada fase kejar tumbuh, ASI memerlukan fortifikasi yang sesuai dengan masing-masing kecukukupan yang dibutuhkan BBLR. ${ }^{19-21}$ Aralnoglu dkk ${ }^{2}$ melaporkan bahwa untuk mencegah terjadinya PEUT yang berhubungan dengan perkembangan neurokognitif dan defisiensi nutrien, pemberian fortifikasi ASI dengan HMF perlu dilakukan $^{22}$ Penelitian metaanalisis yang dilakukan Liu $\mathrm{dkk}^{23}$ tahun 2015, dari 5 studi yang meliputi 352 bayi dengan $\mathrm{BBL} \leq 1750$ gram dan usia kehamilan $\leq$ 34 minggu yang diberikan ASI, menyarankan bahwa penggunaan HMF yang memiliki standar konsentrasi protein tinggi dapat memperbaiki pertumbuhan bayi prematur. $^{23}$

Hasil penelitian ini mendapatkan bahwa bayi prematur dengan fortifikasi HMF memiliki angka kejadian terbanyak $(56,3 \%)$. Keadaan ini dapat disebabkan proses pengenceran fortifikasi HMF dengan ASI yang bervariasi Kebutuhan HMF yang pervolumenya disesuaikan dengan standar pabrik jarang memenuhi kebutuhan protein sesuai rekomendasi seharusnya. Dengan demikian dibutuhkan strategi dalam pemberian HMF, seperti fortifikasi yang disesuaikan ataupun fortifikasi target. ${ }^{24}$ Pada penelitian Arslanoglu dkk 22 tahun 2019, fortifikasi standar dapat memberikan energi yang direkomendasikan, tetapi tidak 
memberikan jumlah protein yang adekuat untuk bayi berat lahir sangat rendah. ${ }^{22}$

Untuk terjadinya PEUT tidak ada perbedaan antara bayi prematur yang diberikan ASI dengan kombinasi ASI ditambah fortifikasi dan susu formula standar prematur. Hasil ini serupa dengan kajian pada tahun 2016 oleh Young yang menemukan bahwa tidak ada perbedaan bermakna pada hasil keluaran pertumbuhan, perkembangan kognitif pada bayi prematur yang diberikan susu formula prematur, susu formula standar, dan susu formula post dischae. ${ }^{25} \mathrm{Hal}$ ini ditunjang dari penelitian $\mathrm{Karagol}^{26}$ pada tahun 2013. Susu formula standar prematur dilaporkan memiliki hasil yang sama dengan kombinasi susu lain untuk mengejar pertumbuhan bayi prematur dengan berat lahir rendah. 26,27 Adanya susu formula standar prematur dijelaskan melalui penelitian Schanle ${ }^{28}$ bahwa komposisi susu formula prematur standar dibuat secara spesifik sesuai untuk kebutuhan bayi premur. ${ }^{28}$

Hasil penelitian ini juga menunjukkan adanya risiko yang sama untuk terjadinya PEUT pada bayi prematur yang diberikan ASI maupun susu formula standar prematur. Hal ini serupa dengan penelitian $\mathrm{Wu}^{29}$ di China yang melaporkan tidak adanya perbedaan bermakna antara grup yang diberikan ASI fortifikasi dengan grup yang diberikan susu formula prematur dalam insiden terjadinya PEUT. ${ }^{29}$

Bayi prematur yang mendapatkan ASI dengan fortifikasi ini memiliki risiko terjadinya PEUT 1,78 lebih tinggi dibandingkan dengan pemberian ASI ditambah susu formula standar prematur. Keadaan ini didukung dengan penelitian Henriksen, ${ }^{30}$ Lemons. ${ }^{31}$ Menurut Henriksen ${ }^{30}$ dan Lemons ${ }^{31}$ fortifikasi pada ASI yang tidak sesuai dengan kecukupan spesifik yang dibutuhkan BBLR akan meningkatkan angka kejadian PEUT dari $33 \%$ ke $55 \%$ pada BBLR. Arslanoglu menjelaskan bahwa terlepas dari adanya pemberian fortifikasi pada ASI untuk bayi prematur, tetap didapatkan pertumbuhan yang lambat dibanding dengan pemberian susu formula standar prematur. Kurangnya kadar protein pada pemberian HMF standar disebabkan karena asumsi yang salah terhadap kadar protein dalam ASI. Konsentrasi protein pada ASI akan menurun pada kisaran $1 \mathrm{~g} / \mathrm{dl}$ saat periode 4-6 minggu laktasi sehingga asupan protein saat periode pemberian HMF standar menjadi tidak adekuat. ${ }^{22}$

Berbeda dengan penelitian lain dari $\mathrm{Li}^{32}$ tahun 2016 dan $\mathrm{Gao}^{14}$ tahun 2018. Li mengatakan bahwa bayi yang diberikan ASI dengan fortifikasi HMF atau ASI dengan kombinasi susu post-discharge formula memiliki kejadian PEUT yang lebih rendah dan peningkatan berat badan yang lebih baik dibandingkan dengan bayi prematur yang diberikan ASI saja atau susu formula standar. Hal ini dapat dikaitkan dengan prosedur pengenceran HMF, yaitu dengan pemberian fortifikasi yang disesuaikan dan pemberian target fortifikasi. ${ }^{22,24}$ Pada penelitian yang dilakukan di UPIN oleh Gao, ${ }^{14}$ bayi dengan berat badan lahir rendah yang diberikan ASI dengan fortifikasi memiliki berat badan, panjang badan dan lingkar kepala yang secara signifikan mendekati populasi dibandingkan dengan bayi prematur yang diberikan susu formula prematur.

Percepatan kenaikan berat badan pada penelitian ini tertinggi didapatkan pada bayi prematur yang mendapat ASI dengan fortifikasi HMF, didukung oleh kepustakaan $\mathrm{Kumar}^{7}$ tahun 2017 dan Penelitian Mukhopdhyay. ${ }^{7}$ Adanya percepatan kenaikan berat badan tertinggi pada bayi prematur yang mendapat ASI dengan fortifikasi HMF ditunjukkan oleh kejadian PEUT terendah pada penelitian ini (16,4\%).

Hasil penelitian ini juga menunjukkan tidak adanya perbedaan percepatan kenaikan berat badan pada bayi prematur menurut jenis nutrisi yang diberikan untuk tercapainya pertumbuhan normal ekstra uteri. $\mathrm{Hal}$ ini didukung melalui penelitian Embleton, ${ }^{33}$ dan Olsen, ${ }^{34}$ untuk mengejar pertumbuhan optimal pada BBLR dibutuhkan komposisi nutrisi individual yang spesifik dan sesuai bagi masing-masing BBLR atau kasus per kasus, tidak dapat dilaksanakan tatalaksana secara umum. Untuk itu, diperlukan pemantauan dan konseling individual agar tercapai tumbuh kembang optimal pada tatalaksana BBLR untuk mencegah terjadinya PEUT. Kumar ${ }^{7}$ melaporkan bahwa untuk pemilihan nutrisi spesifik yang sesuai berdasarkan kebutuhan bayi prematur dengan BBLR merupakan kunci keberhasilan dalam menciptakan tumbuh kembang optimalnya. ${ }^{7,35}$

Keterbatasan pada penelitian ini selain desain retrospektif, juga tidak ada penjelasan tentang prosedur pengenceran fortifikasi HMF pada pemberian ASI pasien yang dipulangkan dari RSAB Harapan Kita.

\section{Kesimpulan}

Pertumbuhan ekstra uteri terhambat (PEUT) merupakan risiko tatalaksana pada bayi prematur. Risiko kejadian PEUT sama pada bayi prematur dengan 
Toto Wisnu Hendrarto dkk: Pengaruh asupan nutrisi pada bayi prematur dengan pertumbuhan ekstrauteri terhambat

pemberian ASI dan ASI kombinasi. Percepatan pertumbuhan tertinggi dialami bayi prematur yang diberikan ASI dan fortifikasi HMF. Untuk terjadinya pertumbuhan normal tidak ada perbedaan percepatan pertumbuhan pada bayi prematur yang diberikan ASI, ASI dengan fortifikasi HMF, ASI dengan susu formula standar ataupun dengan susu formula standar prematur saja. Air susu ibu merupakan pilihan terbaik dalam pemberian nutrisi terhadap bayi prematur, terutama pada periode introduksi pemberian nutrisi enteral dan keadaan kritis BBLR, tetapi untuk mencapai pertumbuhan optimal pada bayi prematur dibutuhkan komposisi nutrisi yang disesuaikan berdasarkan kebutuhannya masing-masing.

\section{Daftar pustaka}

1. Ehrenkranz RA, Das A, Wrage LA, dkk. Early nutrition mediates the influence of severity of illness on 'extremely low birth weight infants. Pediatr Res 2011;69:522-9.

2. Belfort MB, Ehrenkranz RA. Neurodevelopmental outcomes and nutritional strategies in very low birth weight infants. Seminars in Fetal \& Neonatal Med 2016:1-7.

3. Morgan J, Bombell S, McGuire W. Early trophic feeding versus enteral fasting for very preterm or very low birth weight infants (Review). Cochrane Database Syst Rev 2013:1-29.

4. Ehrenkranz RA. Early, Aggressive nutritional management for very low birth weight infants: what is the evidence? Seminars in Perinatol 2007;31:48-55.

5. Prince A, Groh-Wargo S. Nutrition management for the promotion of growth in very low birth weight premature infants. Nutr Clin Pract 2013;28:559-668.

6. Tozzi MG, Moscuzza F, Michelucci A, dkk. Extra uterine growth restriction (EUGR) in preterm infants: growth patterns, nutrition, and epigenetic markers. A pilot study. Frontiers in Pediatr 2018;6:1-9.

7. Kumar RK, Singhal A, Vaidya U, Banerjee S, Anwar F, Rao $S$. Optimizing nutrition in preterm low birth weight infants : consensus summary. Frontiers in Nutr 2017;4:1-9.

8. Eibensteiner F, Auer-Hackenberg L, Jilma B, Thanhaeuser M, Wald M, Haiden N. Growth, feeding tolerance and metabolism in extreme preterm infants under an exclusive human milk diet. Nutrients 2019;11:1-15.

9. Lok KY, Chau PH, Fan HSL, dkk. Increase in weight in low birth weight and very low birth weight infants fed fortified breast milk versus formula milk: a retrospective cohort study. Nutrients 2017;9:1-9.

10. Quigley M, Embleton ND, McGuire W. Formula versus donor breastmilk for feeding preterm or low birth weight infants (Review). Cochrane Database Syst Rev 2018:1-93.

11. Pampanini V, Boiani A, Marchis CD, dkk. Preterm infants with severe extrauterine growth retardation (EUGR) are at high risk of growth impairment during childhood. Eur J Pediatr 2015;174:33-41.

12. Su BH. Optimizing Nutrition in Preterm Infants. Pediatr Neonatol 2014:5-13.

13. 13. Clark RH, Thomas P, Peabody J. Extrauterine growth restriction remains a serious problem in prematurely born neonates. Pediatrics 2003;111:986-90.

14. Gao XY, Feng L, Xu J, Pan XN. Follow-up observation of catch-up growth of preterm infants after discharge and risk factors for extrauterine growth retardation. CJCP 2018;20:438-48.

15. Lin Z, Green RS, Chen S, dkk. Quantification of EUGR as a measure of the quality of nutritional care of premature infants. PLoS ONE 2015;10:1-10.

16. Lee SM, Kim N, Namgung R, Park M, Park K, Jeon J. Prediction of Postnatal Growth Failure among Very Low Birth Weight Infants. Scientific Reports 2018;8:1-8.

17. Simon L, Hanf M, Frondas-Chauty A, dkk. Neonatal growth velocity of preterm infants: The weight $Z$-score change versus Patel exponential model. PLoS ONE 2019;14:1-11.

18. Paudel L, Kalakheti B, Sharma K. Prevalence and outcome of preterm neonates admitted to neonatal unit of a tertiary care center in Western Nepal. JLumbini Med Col 2018;6(2):1-6.

19. Agostoni C, Braegger C, Decsi T, dkk. Role of dietary factors and food habits in the development of childhood obesity: a commentary by the ESPGHAN committee on nutrition. JPGN 2011;52:662-9.

20. Brown JVE, Embleton ND, Harding JE, McGuire W. Multinutrient fortification of humanmilk for preterm infants (Review). Cochrane Database Syst Rev 2016:1-55.

21. Amissah EA, Brown J, Harding JE. Protein supplementation of human milk for promoting growth in preterm infants. Cochrane Database Syst Rev 2018:1-3.

22. Arslanoglu S, Boquien C-Y, King C, dkk. Fortification of human milk for preterm infants: update and recommendations of the European Milk Bank Association (EMBA) Working group on human milk fortification. Frontiers in Pediatrics 2019;7:1-14.

23. Liu T-T, Dang D, Lv X-M, Wang T-F, Du J-F, Wu H. Human milk fortifier with high versus standard protein content for promoting growth of preterm infants: A meta-analysis. J Int Med Res 2015;43:279-89.

24. Kemp J, Wenhold F. Human milk fortification strategies for improved in-hospital growth of preterm infants. South Afr J Clin Nutr 2016;29:157-64. 
Toto Wisnu Hendrarto dkk: Pengaruh asupan nutrisi pada bayi prematur dengan pertumbuhan ekstrauteri terhambat

25. Young L, Embleton N, McGuire W. Nutrient-enriched formula versus standard formula for preterm infants following hospital discharge (Review). Cochrane Database Syst Rev 2016:1-61.

26. Karagol BS, Zenciroglu A, Okumus N, Polin RA. Randomized controlled trial of slow vs rapid enteral feeding advancements on the clinical outcomes of preterm infants with birth weight 750-1250 g. PEN J Parenter Enteral Nutr 2013;37:223-8.

27. Rayyis SF, Ambalavanan N, Wright L, Carlo WA. Randomized trial of "slow" versus "fast" feed advancements on the incidence of necrotizing enterocolitis in very low birth weight infants. J Pediatr 1999;134:293-7.

28. Schanler RJ, Shulman RJ, Lau C. Feeding Strategies for premature infants: beneficial outcomes of feeding fortified human milk versus preterm formula. Pediatrics 1999;103:1150-7.

29. Wu Y, Zhong XY, Jiang J, Gong H. Prospective and controlled study on effect of fortified human milk feeding on infants with extremely and very low birth weight during hospital stay. J Peking University 2016;8:143-7.
30. Henriksen C, Westerberg AC, Rønnestad A, dkk. Growth and nutrient intake among very-low-birth-weight infants fed fortified human milk during hospitalisation. British J Nutr 2009;102:1179-86.

31. Lemons JA, Moye L, Hall D, Simmons M. Differences in the composition of preterm and term human milk during early lactation. Pediatr Res 1982;16:113-7.

32. Li G, Zhang A, Lin H, dkk. Analysis of nutritional status of preterm infants at early life. Dig Med Res 2016;2:1-6.

33. Nicolas E. Embleton NPaRJC. Postnatal malnutrition and growth retardation: an inevitable consequence of current recommendations in preterm infants? Pediatrics 2001;107:270-3.

34. Olsen IE, Richardson DK, Schmid CH, Ausman LM, Dwye JT. Intersite differences in weight growth velocity of extremely premature infants. Pediatrics 2002;110:1125-32.

35. Henderson G, Fahey T, McGuire W. Nutrient-enriched formula milk versus human breast milk for preterm infants following hospital discharge (Review). Cochrane Database Syst Rev 2007:1-11. 